\title{
ANALISIS KECUKUPAN RUANG TERBUKA HIJAU (RTH) KOTA BATAM
}

\author{
Analysis Adequacy Of Green Open Space In Batam City \\ Shirly Indriana Putri ${ }^{1}$, Nurul Qomar ${ }^{2}$, Yossi Oktorini ${ }^{2}$ \\ ${ }^{1}$ Forestry Department, Faculty of Agriculture, Riau University \\ ${ }^{2}$ Bina Widya, Pekanbaru, Riau \\ *Email : Shirlyindrianaputri@yahoo.com
}

Diterima: 27/08/2020, Direvisi: 17/09/2020, Disetujui: 09/02/2021

\begin{abstract}
Batam City is an industrial city with a total area of $1,570.35 \mathrm{~km}^{2}$ with a land area of $715 \mathrm{~km}^{2}$. Along with economic development and an increasing population, the green open space in Batam City is reduced. The purpose of this research was to analyze the adequacy of Batam's green open space based on the criteria of Law No. 26 of 2007 concerning Spatial Planning and Minister of Public Works Regulation No. 5 of 2008 concerning Guidelines and Utilization of Green Open Space. This research was conducted with a spatial analysis method based on land cover information from the interpretation of Landsat $8 \mathrm{OLI}$ image recording on $05-06-2018$. The results showed that Batam's green open space is still 221.400 ha or $32.05 \%$ of the land area. It means Batam City's open space is still sufficient at least 30\% according to Law No. 26 of 2007 and Minister of Public Works Regulation No. 5 of 2008. The most significant land cover in green open space is secondary dryland forest, covering 79.200 ha $(11.45 \%)$.
\end{abstract}

Keywords: analysis, Batam City, green open space.

\section{ABSTRAK}

Kota Batam merupakan kota industri yang memiliki luas wilayah $1.570 .35 \mathrm{~km}^{2}$ dengan luas daratan $715 \mathrm{~km}^{2}$. Seiring dengan perkembangan ekonomi dan jumlah penduduk yang semakin meningkat menyebabkan lahan ruang terbuka hijau di Kota Batam semakin berkurang. Tujuan penelitian ini adalah menganalisis kecukupan ruang terbuka hijau Kota Batam berdasarkan kriteria Undang-Undang No. 26 Tahun 2007 tentang Penataan Ruang dan Peraturan Menteri Pekerjaan Umum No. 5 Tahun 2008 tentang Pedoman dan Pemanfaatan Ruang Terbuka Hijau. Penelitian ini dilakukan dengan metode analisis spasial berdasarkan informasi tutupan lahan hasil interpretasi citra Landsat 8 OLI perekaman tanggal 05-06-2018. Hasil penelitian menunjukkan bahwa ruang terbuka hijau Kota Batam masih seluas 221.400 ha atau 32,05\% dari luas daratan. Dengan demikian, luas Ruang Terbuka Hijau Kota Batam masih mencukupi minimal 30\% sesuai Undang-Undang No. 26 Tahun 2007 dan Peraturan Menteri Pekerjaan Umum No. 5 Tahun 2008. Jenis penutupan lahan terluas pada Ruang Terbuka Hijau di Kota Batam adalah hutan lahan kering sekunder, seluas 79.200 ha $(11,45 \%)$.

Kata kunci: analisis, Kota Batam, ruang terbuka hijau. 


\section{Analisis Kecukupan Ruang Terbuka Hijau... (Putri, dkk)}

\section{PENDAHULUAN}

Kota Batam merupakan kota industri yang memiliki luas wilayah $1.570,35 \mathrm{~km}^{2}$ dengan daratan $715 \mathrm{~km}^{2}$. Pada tahun 1970, Kota Batam merupakan kota dengan hutan yang luas, tetapi sejak tahun 1974 luasnya terus berkurang seiring dengan pembangunan industri dan fasilitas kota, termasuk lahan pinggir laut yang dijadikan civiet, karena seluruh Pulau Batam ditunjuk sebagai daerah industri berdasar Keputusan Presiden Nomor 41 Tahun 1973. Pada tahun 2018, Kota Batam diarahkan menjadi tujuan wisata sehingga pada tahun 2020 dilakukan penataan ruang kembali untuk menjadi kota madani bukan kota industri lagi. Oleh karena itu, keberadaan Ruang Terbuka Hijau (RTH) di kota ini sangat penting untuk diperhatikan.

RTH adalah area memanjang/jalur dan atau mengelompok, yang penggunaannya lebih bersifat terbuka, tempat tumbuh tanaman, baik yang tumbuh tanaman secara alamiah maupun yang sengaja ditanam (Permen PU No. 5 Tahun 2008). RTH di perkotaan mempunyai fungsi untuk menunjang kualitas lansekap kota, meningkatkan produksi oksigen, dan menyerap karbondioksida (Puspitasari et al., 2017) sehingga sangat diperlukan seiring dengan peningkatan jumlah kendaraan. RTH bermanfaat dalam meningkatkan kualitas visual dan estetika kota (Brahmantyo dan Kustiwan, 2012). Kecukupan luas RTH harus diperhatikan agar lingkungan tetap terjaga dan dapat dijadikan tempat rekreasi bagi penduduk di perkotaan (Achsan, 2016). Namun, RTH sering tidak diutamakan dan dianggap sebagai lahan yang tidak bermanfaat karena pemerintah lebih mengutamakan pembangunan gedung-gedung yang dapat meningkatkan nilai ekonomi (Julius, 2014).

Perkembangan ekonomi dan jumlah penduduk yang terus bertambah mengakibatkan peningkatan permintaan kebutuhan ruang terbangun dan mengurangi luas RTH. Pembangunan dari beberapa bidang, seperti permukiman, industri dan gedung telah mengancam keberadaan RTH (Sulma et al., 2016). Menurut Undang-Undang Nomor 26 Tahun 2007 tentang Penataan Ruang dan Peraturan Menteri Pekerjaan Umum Nomor 5 Tahun 2008 tentang Pedoman dan Pemanfaatan Ruang Terbuka Hijau menegaskan bahwa proporsi RTH pada wilayah perkotaan paling sedikit $30 \%$ dari total luas wilayah perkotaan. Pada tahun 2014 , Kota Batam memiliki RTH seluas $33 \%$, dan diperkirakan terus menurun luasnya. Untuk menghitung kecukupan luas RTH di Kota Batam dapat dilakukan melalui penginderaan jauh.

Penginderaan jauh adalah ilmu dan seni untuk memperoleh informasi tentang suatu objek, daerah atau fenomena melalui analisis data yang diperoleh dengan suatu alat tanpa kontak langsung dengan objek, daerah atau fenomena yang dikaji (Lillesand dan Kiffer, 1990). Keuntungan teknologi pengindraan jauh yaitu mempunyai kemampuan dalam menyediakan data atau informasi untuk menjawab pertanyaan khusus berkenaan dengan keruangan (spasial). Tujuan penelitian ini adalah untuk menganalisis kecukupan RTH Kota Batam berdasarkan kriteria Undang-Undang No. 26 Tahun 2007 dan Peraturan Menteri Pekerjaan Umum No. 5 Tahun 2008.

\section{METODE}

Penelitian ini dilakukan di Kota Batam, Kepulauan Riau pada bulan April-Juni tahun 2019. Alat yang digunakan dalam penelitian ini adalah: a) komputer dengan spesifikasi: Intel Core i56200U, CPU @2.30 GHz, RAM 4GB, HDD Memori 500GB dengan system operasi Microsoft Windows 1064 bit, b) software : QGIS 2.18 untuk pengolahan citra satelit, c) Alat pengecekan lapangan : GPSMap Garmin etrex 10, alat tulis dan kamera. Bahan yang digunakan dalam penelitian ini adalah seri citra Landsat 8 OLI path 125 row 59 2018/06/05 yang diperoleh dari USGS (U.S.Geological Survey), peta administrasi Kota Batam dari Badan Pengusahaan (BP) Batam. Penelitian ini dilakukan dengan metode analisis spasial berdasarkan informasi tutupan lahan hasil interpretasi citra Landsat 8 OLI perekaman tanggal 05-06-2018, melalui tahapan proses pemilihan training area, klasifikasi penutup lahan, dan uji akurasi. Analisis kecukupan 
RTH dilakukan dengan menghitung luas RTH berdasar hasil akhir penutup lahan pada citra dan pengecekan lapangan (Rahman et al., 2016). Pengecekan lapangan dilakukan pada lima training area di tiap tutupan lahan yang diperoleh dengan metode klasifikasi terbimbing. Pengecekan di lapangan dilakukan untuk menjaga ketelitian hasil klasifikasi penutup lahan karena semakin banyak kelas penutup lahan yang digunakan tidak berarti semakin akurat hasilnya (Dwiputra et al., 2016), dan untuk menambahkan data lainnya yang tidak dapat dilihat melalui citra (Silviana, 2019). Pengecekan pada 121 titik yang tersebar di 8 kelas penutup lahan sesuai klasifikasi dari Direktorat Jenderal Planologi Kehutanan dan Tata Lingkungan KLHK tahun 2015. Uji akurasi dilakukan dengan metode akurasi kappa SCP (Semi-Automatic Classification PI). Data hasil analisis spasial ditampilkan dalam bentuk peta dan tabulasi, dan dianalisis lebih lanjut secara deskriptif.

\section{HASIL DAN PEMBAHASAN}

Kota Batam beriklim tropis dengan suhu rata-rata $26^{\circ}-34^{\circ} \mathrm{C}$. Kota ini memiliki daratan yang berbukit dan berlembah, serta tumbuhan bakau pada garis pantai. Wilayah Kota Batam

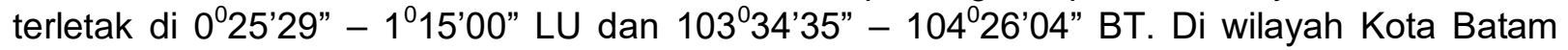
terdapat tiga 3 pulau besar yang dihubungkan dengan jembatan Barelang, yaitu: Pulau Batam, Pulau Rempang, dan Pulau Galang. Selain tiga pulau tersebut, ada beberapa pulau lainnya, antara lain: Pulau Belakang Padang dan Pulau Bulang. Adapun batas-batas wilayah Kota Batam adalah: sebelah utara berbatasan dengan Singapura, sebelah selatan berbatasan dengan Kecamatan Senayang, sebelah timur berbatasan dengan Kecamatan Bintan Utara, dan sebelah barat berbatasan dengan Kabupaten Karimun (Maharani et al., 2016).

\section{Karakteristik Tutupan Lahan di Lapangan}

Berdasar hasil pengamatan di lapangan ditemukan 8 jenis tutupan lahan, terdiri dari: hutan lahan kering sekunder, hutan mangrove, kebun campuran, perkebunan, semak belukar, lahan terbuka, lahan terbangun, dan badan air. Menurut Sreedhar et al. (2016), penutup lahan suatu wilayah merupakan hasil dari beberapa faktor fisik, budaya, dan pemanfaatannya oleh manusia setiap waktu. Hutan lahan kering sekunder ditemukan pada kawasan hutan yang masih terjaga. Wilayah Kota Batam terdiri dari beberapa pulau sehingga ditemukan hutan mangrove di beberapa wilayah pantainya. Tutupan lahan Kota Batam disajikan pada Tabel 1.

Tabel 1. Tutupan Lahan RTH Kota Batam

Table 1. Batam City green open space land cover

\begin{tabular}{|c|c|c|c|c|c|}
\hline No. & $\begin{array}{c}\text { Kelas } \\
\text { Penutup } \\
\text { Lahan }\end{array}$ & Deskripsi & Hasil ground check & Interpretasi Visual & $\begin{array}{c}\text { Titik } \\
\text { koordinat }\end{array}$ \\
\hline 1. & Hutan & $\begin{array}{l}\text { Suatu hamparan } \\
\text { yang ditumbuhi } \\
\text { pepohonan } \\
\text { kompak dan } \\
\text { rapat yang } \\
\text { berada di wilayah } \\
\text { perkotaan dan } \\
\text { telah ditetapkan } \\
\text { oleh pemerintah } \\
\text { setempa. }\end{array}$ & & gor selupang & $\begin{array}{l}\text { LU } \\
11^{\circ} 27^{\prime} 82^{\prime \prime} \\
\mathrm{BT} \\
103^{\circ} 93^{\prime} 37^{\prime \prime}\end{array}$ \\
\hline
\end{tabular}


Analisis Kecukupan Ruang Terbuka Hijau... (Putri, dkk)

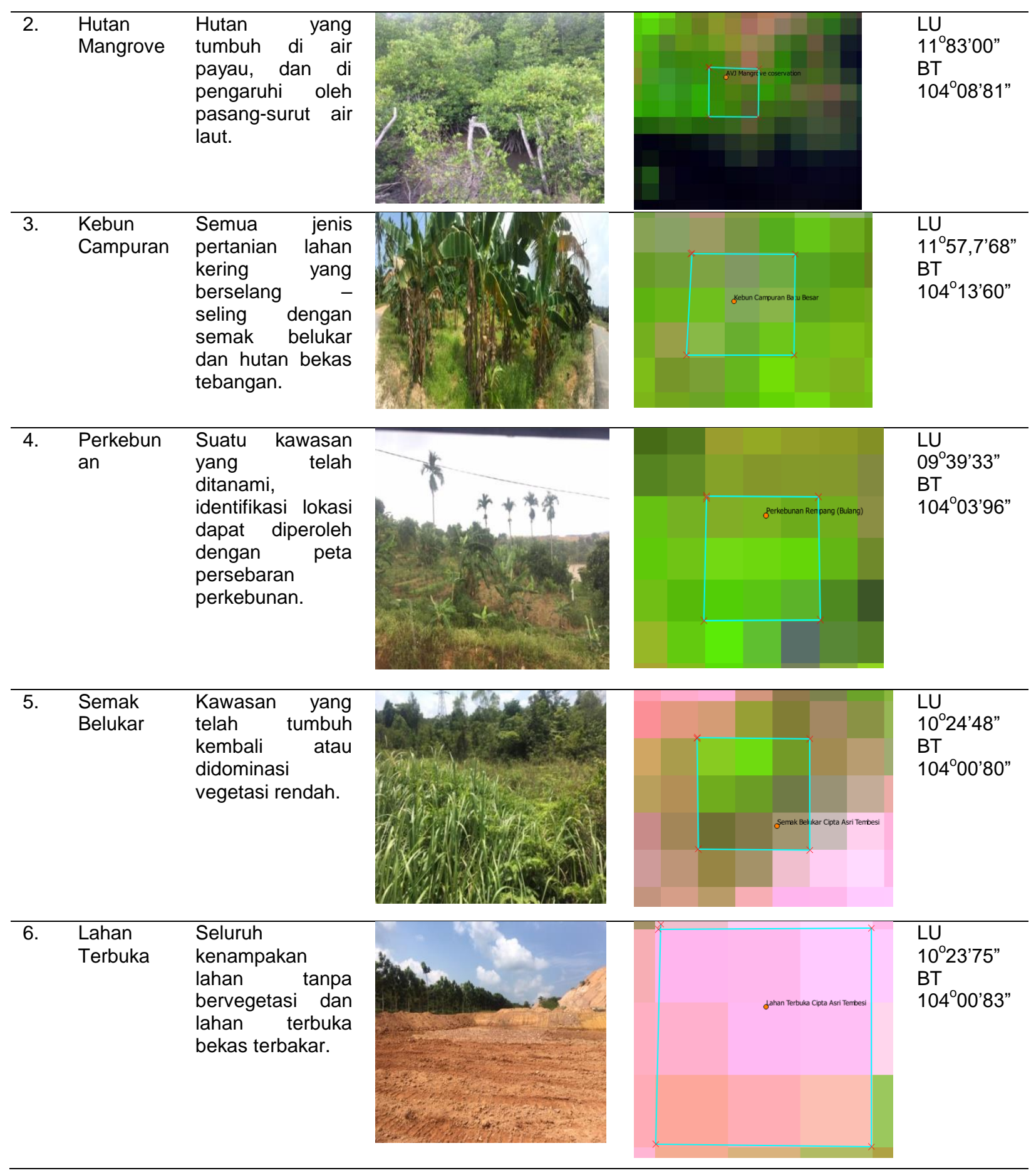




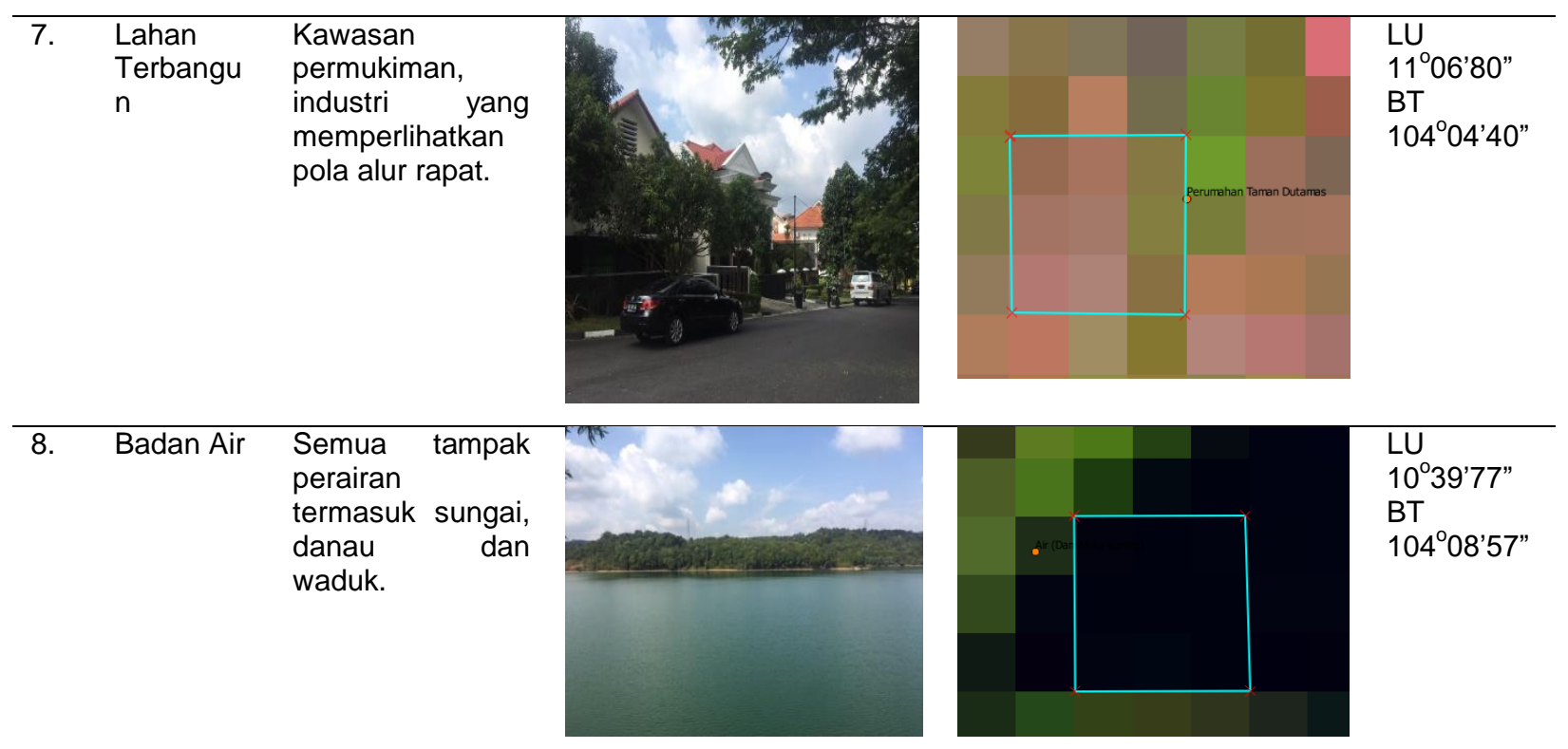

Sumber : Analisis data (2019)

\section{Karakteristik Tutupan Lahan secara Visual}

Berdasarkan hasil klasifikasi tutupan lahan secara visual dengan menggunakan citra Landsat 8 OLI tahun 2018 diperoleh 8 jenis kelas tutupan lahan, terdiri dari: hutan lahan kering sekunder, hutan mangrove, kebun campuran, perkebunan, semak belukar, lahan terbuka, lahan terbangun dan badan air. Peta hasil klasifikasi penutup lahan Kota Batam dapat dilihat pada Gambar 1.

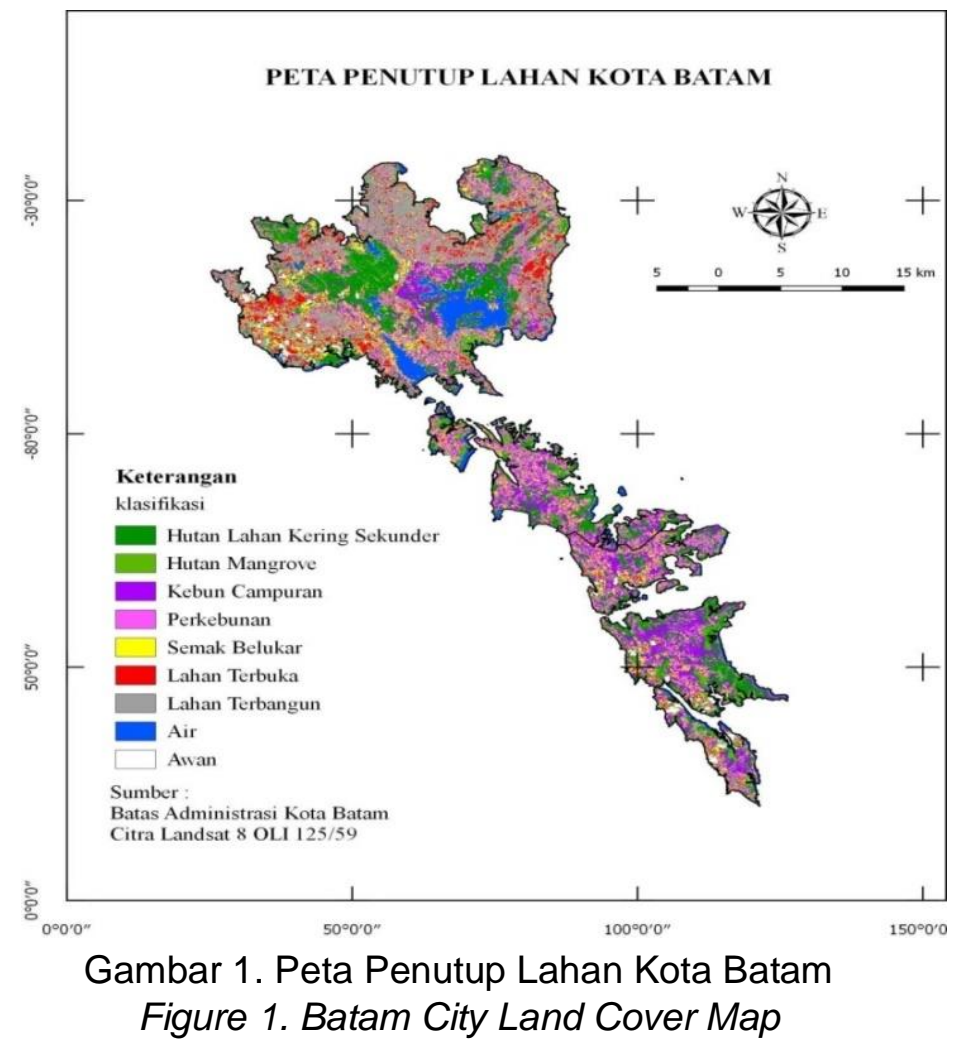




\section{Perhitungan Uji Akurasi}

Pada penelitian ini, seluruh proses pendugaan akurasi dilakukan di QGIS dengan metode akurasi kappa SCP (Semi-Automatic Classification PI). Sampel yang digunakan sebanyak total training area yang dibuat. Perhitungan uji akurasi hasil klasifikasi pada citra dapat dilihat pada Tabel 2. Hasil uji akurasi menunjukkan bahwa nilai overall accuracy sebesar $90,47 \%$ dan kappa accuracy sebesar $87,26 \%$. Menurut Jaya (2010), nilai akurasi yang baik adalah nilai akurasi yang telah mencapai skor $>85 \%$, artinya hasil klasifikasi penutup lahan pada penelitian ini dapat digunakan karena nilai kappa accuracy-nya $>85 \%$. Hasil akurasi ini dipengaruhi oleh algoritma maximum likelihood classification yang digunakan (Foody et al., 1992; Manandhar et al., 2009). Luas tutupan lahan Kota Batam berdasarkan hasil uji akurasi dapat dilihat pada Tabel 3.

Tabel 2. Akurasi tutupan lahan tahun 2018

Table 2. Land cover accuracy in 2018

\begin{tabular}{|c|c|c|c|c|c|c|c|c|c|c|}
\hline Kelas & HLKS & $\mathrm{HM}$ & KC & $P$ & SB & LT & LB & BA & $\begin{array}{l}\text { Total } \\
\text { baris }\end{array}$ & UA (\%) \\
\hline HLKS & 6,84 & 0,18 & 0 & 0,9 & 0 & 0 & 0 & 0 & 7,92 & 86,36 \\
\hline HM & 0,09 & 2,97 & 0 & 0 & 0 & 0 & 0 & 0 & 3,06 & 97,05 \\
\hline $\mathrm{KC}$ & 0 & 0 & 1,63 & 1,69 & 2,26 & 0 & 0 & 0 & 5,58 & 88,70 \\
\hline$P$ & 0 & 0 & 0 & 3,43 & 2,15 & 0 & 0 & 0 & 5,58 & 94,23 \\
\hline SB & 0 & 0 & 0 & 0,63 & 1,26 & 0 & 0,99 & 0 & 2,88 & 85,87 \\
\hline LT & 0 & 0 & 0 & 0 & 0 & 3,96 & 0,63 & 0 & 4,59 & 92,74 \\
\hline LB & 0 & 0 & 0 & 0 & 0,18 & 0,45 & 35,55 & 0 & 36,18 & 98,25 \\
\hline BA & 0 & 0 & 0 & 0 & 0 & 0 & 0 & 5,07 & 5,07 & 100,0 \\
\hline $\begin{array}{l}\text { Total } \\
\text { kolom }\end{array}$ & 6,93 & 3,15 & 1,63 & 6,65 & 5,85 & 4,41 & 37,17 & 5,07 & 70,86 & \\
\hline PA (\%) & 98,70 & 94,28 & 100,0 & 89,0 & 94,33 & 91,67 & 96,57 & 100,0 & & \\
\hline
\end{tabular}

Overall Accuracy $(\%)=90,47$

Kappa Accuracy $(\%)=87,26$

Ket : HLKS = Hutan lahan kering sekunder; $\mathrm{HM}=$ Hutan mangrove; $\mathrm{KC}=$ Kebun campuran; $\mathrm{P}=$ Perkebunan; $\mathrm{SB}=$ Semak belukar; $\mathrm{LT}=$ Lahan terbuka; $\mathrm{LB}=$ Lahan terbangun; BA = Badan Air; $\mathrm{UA}=$ User's accuracy; PA = Producer's accuracy

Tabel 3. Luas tutupan lahan berdasarkan hasil uji akurasi Table 3. Land cover area based on accuracy test results

\begin{tabular}{clrr}
\hline No. & \multicolumn{1}{c}{ Tutupan Lahan } & Luas (ha) & Proporsi (\%) \\
\hline 1. & Hutan Lahan Kering & 79.200 & 11,45 \\
& Sekunder & & \\
2. & Hutan Mangrove & 30.600 & 4,42 \\
3. & Kebun Campuran & 55.800 & 8,07 \\
4. & Perkebunan & 55.800 & 8,07 \\
5. & Semak Belukar & 28.800 & 4,16 \\
6. & Lahan Terbuka & 45.900 & 6,64 \\
7. & Lahan Terbangun & 360.000 & 52,08 \\
8. & Badan Air & 35.100 & 5,07
\end{tabular}

\section{Sumber: analisis hasil olahan data}

Tabel 3 menunjukkan bahwa tutupan lahan terluas adalah lahan terbangun seluas 360.000 ha $(52,08 \%)$ diikuti hutan lahan kering sekunder seluas 79.200 ha $(11,45 \%)$. Berdasar data pada Tabel 3, kelas penutup lahan yang termasuk dalam tipe RTH menurut Peraturan Menteri Pekerjaan Umum Nomor 5 Tahun 2008 adalah: 1) kebun campuran, 2) perkebunan, 3) hutan 
lahan kering, dan 4) hutan mangrove. Ada dua tipe RTH berdasarkan kelas penutup lahan Kota Batam, yaitu sabuk hijau dan hutan kota (Tabel 4).

Tabel 4. Tipe RTH berdasarkan kelas penutup lahan

Table 4. Green open space type based on land cover class

\begin{tabular}{|c|c|c|c|c|}
\hline No & Tipe RTH & Penutup Lahan & Luas (ha) & Persentase (\%) \\
\hline$\underline{A}$ & $\underline{\mathrm{RTH}}$ & & & \\
\hline 1 & & Kebun Campuran & 55.800 & 8,07 \\
\hline 2 & Sabuk HIJau & Perkebunan & 55.800 & 8,07 \\
\hline 3 & & Hutan Lahan Kering & 79.200 & 11,45 \\
\hline & Hutan Kota & Sekunder & & \\
\hline 4 & & Hutan Mangrove & 30.600 & 4,46 \\
\hline & \multicolumn{2}{|c|}{ Sub Total } & 221.400 & 32,05 \\
\hline$\underline{B}$ & Non RTH & & & \\
\hline$\overline{5}$ & & Semak Belukar & 28.800 & 4,16 \\
\hline 6 & & Lahan Terbangun & 360.000 & 52,08 \\
\hline 7 & & Badan Air & 35.100 & 5,07 \\
\hline 8 & & Lahan Terbuka & 45.900 & 6,64 \\
\hline \multicolumn{3}{|c|}{ Sub Total } & 469.800 & 67,95 \\
\hline & Total & & 691.200 & 100,00 \\
\hline
\end{tabular}

Tabel 4 menunjukkan bahwa luas RTH Kota Batam mencapai 221.400 ha atau $32,05 \%$ dari total luas wilayah kota. Angka ini masih memenuhi kriteria Undang-Undang No. 26 Tahun 2007 dan Peraturan Menteri Pekerjaan Umum No. 5 Tahun 2008, bahwa minimal RTH di kawasan kota sebesar 30\% dari luas wilayah kota. Namun, jika dibandingkan dengan luas RTH tahun 2016 seluas 221.730 ha, maka terjadi pengurangan seluas 330 ha dikarenakan banyak pembangunan terutama untuk pemukiman dan bangunan gedung di pusat kota. Kondisi ini hampir terjadi di semua kota di Indonesia, misalnya pengurangan luas RTH karena berubah menjadi kawasan terbangun seperti permukiman dan perdagangan di Kota Pekanbaru (Aini et al., 2015; Damanik et al., 2019) dan di Kota Malang (Ekawati et al., 2013).

Hutan lahan kering di Kota Batam menutupi $11.45 \%$ dari keseluruhan RTH karena keberadaannya sangat dijaga oleh pemerintah daerah dan Badan Pengusahaan (BP) Batam karena penting untuk melindungi daerah resapan air, dimana ketersediaan air tawar di pulau ini sangat dibutuhkan untuk konsumsi rumah tangga maupun industri. Kualitas daerah resapan air sangat bergantung dari tutupan hutan di atasnya, terlebih untuk daerah dengan tanah bauksit seperti Kota Batam. Untuk memenuhi kebutuhan air tawar tersebut, ada 9 waduk di Kota Batam, beberapa di antaranya: Duriangkang, Tembesi, Sei Harapan, Sei Ladi dan Sei Gong. Pemerintah pun menunjuk beberapa kawasan Hutan Lindung di sekitar waduk untuk menjaga kuantitas dan kualitas air di waduk tersebut. Hutan lahan kering juga dapat ditemukan di Taman Wisata Alam Muka Kuning dan Taman Buru Rempang. Kementerian Lingkungan Hidup dan Kehutanan (KLHK) terus berusaha mempertahankan kawasan hutan di Kota Batam untuk menjaga ekosistem di Pulau Batam dan pulau-pulau kecil di sekitarnya. Komitmen ini perlu didukung oleh arahan kebijakan dan keinginan yang kuat dari pemerintah daerah untuk dapat mewujudkanya (Samsudi, 2010).

Sebaran RTH Kota Batam dapat dilihat pada Gambar 2, dimana RTH tersebar merata di semua kecamatan. Hutan lahan kering tersebar di lima kecamatan, yaitu: Sekupang, Batu Aji, Batu Ampar, Sei Beduk dan Nongsa. Proporsi RTH di Pulau Batam, Pulau Rempang, dan Pulau Galang juga masih cukup tinggi, mencapai $47,46 \%$ (Tabel 5). Data ini menunjukkan bahwa kecukupan luas dan sebaran RTH di Kota Batam masih memenuhi kriteria sesuai UndangUndang No. 26 Tahun 2007 dan Peraturan Menteri Pekerjaan Umum No. 5 Tahun 2008. 


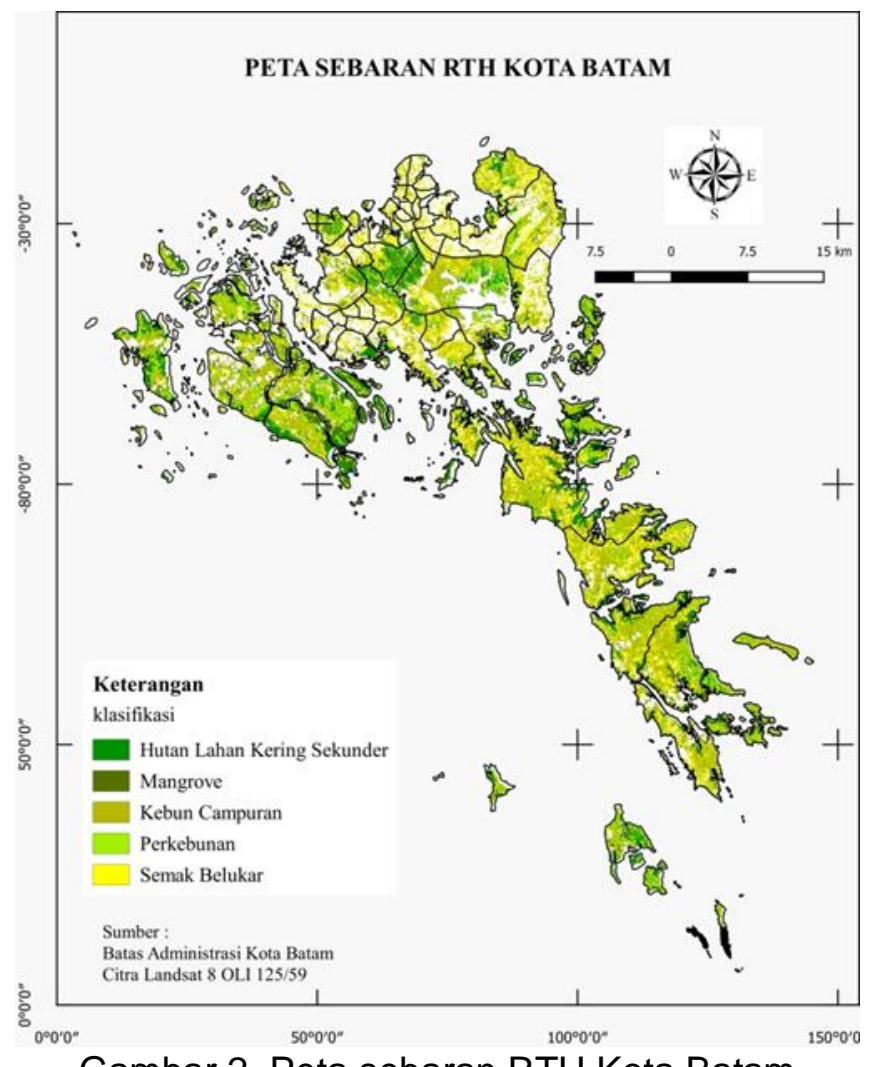

Gambar 2. Peta sebaran RTH Kota Batam

Figure 2. Batam City Green Open Space Distribution Map

Tabel 5. Luas dan proporsi RTH di tiga pulau besar di Kota Batam

Table 5. The area and proportion of green open space in the three major islands in Batam City

\begin{tabular}{|c|c|c|c|c|}
\hline No. & Pulau & Luas Pulau (ha) & $\begin{array}{l}\text { Luas } \\
\text { (ha) }\end{array}$ & $\begin{array}{l}\text { Proporsi RTH } \\
(\%)\end{array}$ \\
\hline 1. & Batam & 71.500 & 35.300 & 49,37 \\
\hline 2. & Rempang & 16.500 & 6.400 & 38,78 \\
\hline 3. & Galang & 31.250 & 14.900 & 47,68 \\
\hline & Total & 119.250 & 56.600 & 47,46 \\
\hline
\end{tabular}

\section{KESIMPULAN DAN SARAN}

Luas RTH Kota Batam mencapai 221.400 ha atau 32,05\% dari luas daratan, dengan demikian masih mencukupi batasan minimal 30\% sesuai Undang-Undang No. 26 Tahun 2007 dan Peraturan Menteri Pekerjaan Umum No. 5 Tahun 2008. Jenis RTH paling luas adalah hutan lahan kering sekunder, seluas 79.200 ha $(11,45 \%)$. adapun saran yang diajukan dalam penelitian ini yaitu diperlukan peranan Badan Pengusahaan (BP) Batam, Pemerintah Kota Batam, Dinas LHK Provinsi Kepulauan Riau, serta Kementerian LHK dalam meningkatkan pengelolaan RTH sehingga kualitasnya terjaga dan berfungsi maksimal. Perlu penelitian lanjutan dengan menggunakan citra terbaru dan resolusi tinggi, serta 
menggunakan metode klasifikasi berbasis objek untuk mendapat hasil yang lebih akurat.

\section{DAFTAR PUSTAKA}

Achsan, A.C. 2016. Analisis Ketersediaan dan Kebutuhan Ruang Terbuka Hijau Pada Kawasan Pusat Pelayanan Kota (Studi Kasus Kecamatan Palu Timur, Kota Palu). Jurnal Arsitektur Lansekap Vol 2(1): 83-92. doi.org/10.24843/JAL.2016.v02.i01.p09.

Aini, L.N., Isnawan, B.H, Saleh, E.R. 2015. Evaluasi Ruang Terbuka Hijau di Kota Pekanbaru. Planta Tropika Journal of Agro Science 3 (1): 41-51. doi.org/10.18196/pt.2015.038.41-51.

Brahmantyo, T. Kustiwan, I. 2012. Evaluasi Penyediaan Ruang Terbuka Hijau Sebagai Infrastruktur Hijau di Kota Bogor dan Cirebon. Jurnal Perencanaan Wilayah dan Kota 2(1): 54-60.

Damanik, P.C., Jhonnerie, R., Qomar, N. 2019. Analisis Kebutuhan Ruang Terbuka Hijau (RTH) di Kota Pekanbaru. Prosiding Seminar Nasional Teknologi dan Pengelolaan Lingkungan Tropis oleh Program Studi Teknik Lingkungan Universitas Riau. Pekanbaru, 21-22 Agustus 2019.

Direktorat Jenderal Planologi Kehutanan dan Tata Lingkungan KLHK. 2015. Rekalkulasi Penutupan Lahan Indonesia Tahun 2014.

Dwiputra, A.J., Suharyadi, R., Danoedoro, P. 2016. Pengaruh Jumlah Kelas dan Skema Klasifikasi Terhadap Akurasi Informasi Penggunaan Lahan Hasil Klasifikasi Berbasis Objek Dengan Teknik Support Vector Machine di Sebagian Kabupaten Kebumen Provinsi Jawa Tengah. Majalah Geografi Indonesia 30 (2): 120-133.

Ekawati, N.N., Soeaidy, M.S., Ribawanto, H. 2013. Kajian Dampak Pengembangan Pembangunan Kota Malang Terhadap Kemacetan Lalu Lintas (Studi pada Dinas Perhubungan Kota Malang). Jurnal Administrasi Publik (JAP) 2 (1): 129-133.

Foody, G.M., Campbell, N.A., Trodd, N.M., Wood, T.F. 1992. Derivation and Applications of Probabilistic Measures of Class Membership from the Maximum-Likelihood Classification. Journal American Society for Photogrammetry and Remote Sensing 58 (9): 1335-1341.

Jaya, I.N.S. 2010. Analisis Citra Digital: Perspektif Penginderaan Jauh untuk Pengelolaan Sumber Daya Alam. Institut Pertanian Bogor Press. Bogor.

Julius, R.R. 2014. Strategi Pemerintah Kota Pekanbaru Dalam Meningkatkan Ruang Terbuka Hijau di Kota Pekanbaru. Jurnal FISIP Universitas Riau. Hal 2.

Keputusan Presiden Nomor 41 Tahun 1973 Tentang Daerah Industri Pulau Batam.

Lillesand, T. M., Kiffer, R.W. 1990. Penginderaan Jauh dan Interpretasi Citra. Gadjah Mada University Press. Yogyakarta.

Maharani, Kurniasih., Chaidir, A., Sangaji, Aditya, Diah, A.P. 2017. Kota Batam Dalam Angka 2017. Badan Pusat Statistik Kota Batam: Batam.

Manandhar, R., Odeh, I.O.A, Ancev, T. 2009. Improving the Accuracy of Land Use and Land Cover Classification of Landsat Data Using Post-Classification Enhancement. Remote Sensing 1: 330-344. doi:10.3390/rs1030330

Peraturan Menteri Pekerjaan Umum No. 5 Tahun 2008. Pedoman Penyediaan dan Pemanfaatan Ruang Terbuka Hijau di Kawasan Perkotaan Nomor : 05/PRT/M/2008. Direktorat Jendral Penataan Ruang, Departemen Pekerjaan Umum, Jakarta. 
Puspitasari, D.A., Aini, L.N., Isnawan, B.H. 2017. Evaluasi Ruang Terbuka Hijau (RTH) Taman Kota Dan Jalur Hijau Jalan Di Kecamatan Bantul. Jurnal Fakultas Pertanian UMY: 1-13.

Rahman, M.D., Awaluddin, M., Hani'ah. 2016. Analisis Spasial Ketersediaan Ruang Terbuka Hijau Terhadap Jumlah Penduduk di Kota Solo. Jurnal Geodesi Undip 5 (3): 41-51.

Samsudi. 2010. Ruang Terbuka Hijau Kebutuhan Tata Ruang Perkotaan Kota Surakarta. Journal of Rural and Development 1 (1): 11-19.

Silviana, M. 2019. Monitoring Perubahan Tutupan Lahan Hutan lindung Bukit Suligi Kabupaten Kampar Provinsi Riau. Universitas Riau. Pekanbaru.

Sreedhar, Y., Nagaraju, A., Krishna, G.M. 2016. An Appraisal of Land Use/Land Cover Change Scenario of Tummalapalle, Cuddapah Region, India. Journal Advances in Remote Sensing 5: $232-245$.

Sulma, S., Nugroho, J.T., Zubaidah, S., Fitriana, H.L., Haryani, N.S. 2016. Detection of Green Open Space Using Combination Index of Landsat 8 Data. International Journal of Remote Sensing and Earth Sciences Remote Sensing 13 (1): 1-8.

Undang Undang No. 26 Tahun 2007 tentang Penataan Ruang.

USGS. 2016. Landsat 8 (L8) Data User Handbook. Department of the Interior U.S. Geological Survey Vol 2.0: 1-91. 